\title{
PERSONAL BIOLOGY TEACHING EFFICACY BELIEFS AND BIOLOGY TEACHING OUTCOME EXPECTANCY OF IN-SERVICE ELEMENTARY TEACHERS
}

\author{
Eirini Tzovla ${ }^{i}$, \\ Katerina Kedraka \\ Laboratory of Teaching and \\ Professional Development of Bioscientists, \\ Department of Molecular Biology and Genetics, \\ Democritus University of Thrace, \\ Greece
}

\begin{abstract}
:
The role of the teacher is of great importance in learning and his beliefs affect effectiveness of teaching in every cognitive object. This paper deals with the personal selfefficacy beliefs and the outcome expectancy of in-service teachers teaching biological concepts in Primary School. The study was conducted with 509 in-service elementary teachers and the bio-STEBI-A, which is an adaptation of STEBI-A, was used as the data collection instrument. The results of our survey indicated that in-service elementary teachers scored moderate self-efficacy and their personal self-efficacy beliefs were found to be greater than their outcome expectancy. Recommendations are made for future research.
\end{abstract}

Keywords: in-service elementary teachers, biological concepts, self-efficacy

\section{Introduction}

Teachers play a very important role in the educational process and their beliefs and especially their self-efficacy beliefs affect the way they teach, the choice of their instructional practices and the learning outcomes (Fives \& Buehl, 2012; Gibson \& Dembo, 1984). Regarding Science, Cox and Carpenter (1989) emphasize the importance of selfefficacy beliefs in shaping attitudes. This thesis is shared by Akgün, Keskin, and Byrne (2009) who report that negative attitude towards science causes low self-efficacy in teachers. As a result, teachers with low self-efficacy adopt the teacher-cantered teaching model, are critical of the students, focus on external motivations, find it difficult to set goals for their students (Brownell \& Pajares, 1999; Mojavezi \& Tamiz, 2012), and do not

\footnotetext{
i Correspondence: email etzovla@mbg.duth.gr
} 
involve the students in scientific activities (Bleicher, 2007; Gunning \& Mensah, 2011; Sarıkaya, Cakiroglu, \& Tekkaya, 2005), despite that involving the students in such activities is of great importance for the scientific literacy.

Given that the Covid19 pandemic affects our life, scientific literacy, and especially biological literacy, is more necessary and urgent now than ever. In situations of pandemics, the well-informed individual behaviour is the main point. Given that 1.3 billion students from all levels of education in 142 countries were affected by the lockdown (UNESCO, 2020), it becomes clear that students should be aware of the reality they experience in order to make decisions as active citizens (Bryce et al., 2011). The pandemic also affected cognitive objects (Snyder, 2020) and made the teaching of biological concepts, possibly in a violent way, important. Hence, teachers face a great challenge of effectively teaching biological concepts to their students.

\section{Theoretical Framework}

The socio-cognitive theory of learning interprets behaviour as a result of the interaction of personal, behavioural, and environmental factors (Bandura, 1977, 1982). One of the basic concepts of Bandura's theory is the concept of self-efficacy, which regards the way in which a person perceives himself and interprets events around him, and this determines both his motives and his expectations.

Bandura (1997) attributes a significant role to one's expectations of oneself but also to circumstances and advocates that the belief in something is just as important as the skills, abilities and knowledge to achieve that thing. These expectations are linked to selfefficacy beliefs, which Bandura (1977, p. 194) defines as "beliefs in one's ability to organize and perform the actions required to achieve goals" and to analyse it in two dimensions: the personal self-efficacy and outcome expectancy. Also, he argues that selfefficacy beliefs are shaped by four sources: mastery experiences, vicarious experiences, physical and emotional states, and verbal persuasion (Bandura, 1997).

Moreover, Bergman et al., (1977 б.137 as cited in Brouwers \& Tomic, 2000) define teachers' self-efficacy as "the degree to which a teacher is convinced that he has the ability to influence the achievements of his students". Pajares (1996) and Tschannen-Moran, Woolfolk Hoy, and Hoy (1998) note that this refers to teachers' perceptions of their ability to help students learn and Goddard, Hoy and Hoy (2000, p. 482) note that "teachers do not feel equally effective in all teaching subjects."

\section{Self-efficacy Instruments}

Self-efficacy is measured by psychometric tests, which assess a person's beliefs of their abilities and self-efficacy instruments aim to measure a person's confidence in a particular behaviour. The most well-known instruments are self-report questionnaires, which include statements that relate to the individual's certainty about his performance in a particular project. 
In this term, Gibson and Dembo (1984) developed the "Teacher Efficacy Scale" (TES), the use of which is more common than any other instrument for measuring selfefficacy, and which is based on Rotter's theory (1966) and especially on Bandura theory (1977). Initially, it consisted of thirty (30) statements which were then limited to sixteen (16), graded on the Likert scale and measures the two dimensions of self-efficacy, personal teaching efficacy, (PTE, 9 statements) associated with Bandura's personal selfefficacy scale and general teaching efficacy (GTE, 7 statements) associated with Bandura's outcome expectancy scale.

Tschannen-Moran and Hoy (2001) created a multidimensional scale, the Teachers' Sense of Efficacy-TSES, to measure three (3) parameters of the learning process: teaching strategies, classroom management, and student engagement. This instrument is based on Bandura's theory (1977) and is presented in two forms. One consists of 24 statements and the other is shorter, which consists of 12 statements. Dellingerer et al. (2008) also construct the TEBS-Self instrument (Teachers 'Efficacy Beliefs System - Self), which assesses teachers' self-efficacy related to effective teaching and learning in their class. It consists of thirty (30) statements, which are answered on a four-grade scale. Bandura (1997) also created an instrument for measuring teachers' self-efficacy. This includes seven (7) subscales and 30 statements on a ninth grade scale.

Focusing on Science, Baldwin, Ebert-May and Burns (1999) created the Biology Self-Efficacy Scale, which measured pre-service teachers' self-efficacy in understanding and using Biology in their lives. Smolleck Zembal-Saul and Yoder (2006) developed the Teaching Science as Inquiry (TSI) instrument, which is based on the National Science Education Standards (NRC, 2000), measures personal self-efficacy and expected outcomes for elementary teachers and emphasizes inquiry-based learning. Riggs and Enochs (1990) constructed "The Science Teaching Efficacy Belief Instrument" (STEBI-A for in-service elementary teachers and STEBI B for pre-service elementary teachers, which is based on the Gibson and Dembo instrument (1984) and has been used in numerous studies that measure teachers' self-efficacy in Science. It consists of two subscales: a) Personal Science Teaching Efficacy (PSTE), and b) Science Teaching Outcome Expectancy (STOE). The STEBI-A, which regards in-service elementary teachers, includes twenty-five (25) items of which thirteen (13) measure the PSTE, and twelve (12) measure (STOE). Initially, this instrument was used to measure self-efficacy of elementary teachers in science and later it was modified and adapted to measure other school subjects.

Furthermore, in Asia, other instruments for measuring self-efficacy have been developed by researchers. Shum and Cheng (1997) measured the self-efficacy of femaleleader teachers, Yeung and Watkins (2000) measured personal self-efficacy, and Kennedy and Hui (2006) developed the Chinese version of Teachers' Sense of Efficacy Scale (TSE).

\section{Literature Review}

The literature review did not reveal a significant number of recent studies investigating teachers' self-efficacy in teaching biological concepts. In fact, most of the studies focus on 
pre-service teachers, measure their self-efficacy in Science using STEBI B (Avery \& Meyer, 2012; Aurah \& McConnell, 2014, Aydin \& Boz, 2010; Bayraktar 2011; Bergman \& Morphew, 2015; Bursal, 2012; Gray, 2017; Hechter, 2011; Norris, Morris \& Lummis, 2018). Specifically, Avery and Meyer (2012) refer that the inquiry-based science courses correlate positively with pre-service teachers' science self-efficacy. Aurah and McConnell (2014) and Bursal (2012) found that gender does not affect self-efficacy beliefs and Aurah and McConnell (2014), who compared the differences in self-efficacy beliefs between preservice teachers in the United States and Kenya, referred that students from the USA scored higher than students from Kenya in PSTE, while students from Kenya scored higher in STOE. Aydin and Boz (2010) investigated pre-service teachers' self-efficacy in Turkey and found that self-efficacy beliefs of pre-service teachers are generally high for both subscales and graduate students had higher PSTE and STOE than other students. In addition, Hechter (2010) reported that the number of postgraduate courses students had attended affects PSTE but not STOE. Bergman \& Morphew (2015) indicated that preservice teachers had high PSTE and moderate to high STOE.

Similarly, there is a wide range of studies regarding in-service teachers' selfefficacy in teaching Science, which has used the STEBI-A instrument. Evans (2012) Gosselin et al. (2010) and Ulmer et al. (2013) reported that Teachers Professional Development (TPD) courses increase in-service teachers self-efficacy, and Lakshmanan et al. (2010) found that this kind of courses improved in-service teachers PSTE but not STOE. Also, Lumpe et al. (2012) reported that TPD courses improve PSTE, men had more positive beliefs about Science than women and hours of attending TPD courses were an important predictor of learning achievement. Additionally, Albion and Spence (2013) refer mediate science self-efficacy in elementary teachers in Australia and McKinnon, Jase Moussa-Inaty and Barza (2014) indicated that in-service teachers had low science selfefficacy and teachers, who had between one and three years of experience had the highest PSTE. Moreover, Yenice (2009) found that there were no differences in gender, age, training received by teachers but there were differences as far as seniority was concerned. Despite the growing rates of applying studies in teachers' self-efficacy in Science, there are a small number of studies that measure pre-service or in-service elementary teachers' self-efficacy in teaching biological concepts. In this regard, Mavrikaki and Athanasiou (2011) found that the self-efficacy of in-service elementary teachers increased with teaching experience, additional studies were not related to self-efficacy, teachers who taught upper grade had higher self-efficacy, those who had attended science orientation in High School have higher self-efficacy than those who had attended humanity orientation and the number of Biology or Science courses they had attended in their basic studies was positively related to their self-efficacy in science teaching. Respectively, Angle and Moseley (2009) investigated the self-efficacy of Biology teachers in the Secondary School and reported that no correlation was recorded between self-efficacy and years of experience and Biology orientation teachers had the same scores on personal self-efficacy beliefs as non-Biology orientation teachers, while Biology orientation teachers had higher scores on outcomes expectancy. 
Regarding the research, which was conducted with pre-service teachers, Savran and Cakiroglou (2001) reported no differences regarding gender and the attendance of previous courses on Biology and Gercek et al., (2006) found that students showed high self-efficacy and there were no differences in their self-efficacy in relation to age, gender, academic achievement while there were differences in self-efficacy in relation to the Biology lessons that the students had attended.

Also, the results of the Çimen et al., (2011) research showed that students' selfefficacy beliefs about Environmental Education were high and improved as the level of study of Biology students improved and Ekici, Fettahlığlu and Çıbık (2012), who investigated students' self-efficacy beliefs from two Biology departments, indicated that the university had a low impact on student self-efficacy and none on the year of study, while students' self-efficacy beliefs were moderate and students' self-efficacy beliefs in the Biology department for education were higher than those of the Biology department students. Moreover, Saribas, Teksoz and Ertepinar (2014) found that students' selfefficacy beliefs related to environmental education and environmental knowledge are both moderate. Also, Ateş and Saylan (2015) found that students' academic self-efficacy and academic motivation were high and the university affects academic self-efficacy and academic motivation and Yilmaz, Gunes and Katigcioglu (2016) reported that students have high levels of self-efficacy and academic self-efficacy. Furthermore, Posnanski (2002) investigated the effect of a TPD course on biological concepts. The results reported that PSTE increased statistically as opposed to STOE.

\section{Research Aim}

The present study attempted to investigate Greek in-service elementary teachers' efficacy beliefs regarding teaching biological concepts. For this reason, we adapted STEBI-A developed by Enochs and Riggs (1990) in Greek content and constructed the bio-STEBIA instrument.

\section{Method}

\subsection{Procedure and Sample}

The present study was conducted during the academic year 2019-2020 and the participation in the study was voluntary. The instrument's final version was created with Google Forms and the participants were informed about the purpose of the study and that anonymity would be maintained.

The final sample of the present study was composed of 509 in-service elementary teachers and the majority of them were female $(\mathrm{N}=361)$. Regarding the age, 87 of them were under 30 years old, 132 were between 31- 40, 117 between 41- 50, and 173 up to 51 years old. As far as years of experience was concerned, 87 had less than 5 years, 36 had 6-10 years of teaching experience, 193 had 11-20 and 193 had more than 21 years of experience. From 509 teachers who participated in the survey, 117 had attended Science 
orientation in the last grade in Lyceum, 106 had attended the Economic \& Computer orientation and 286 had attended the Humanities orientation. Moreover, 270 had postgraduate studies and 46 taught in first and second grade, 41 in third and fourth grade, 127 in fifth and sixth grade and 295 in all grades of primary school (Table 1).

Table 1: Demographic Characteristics of teachers $(\mathrm{N}=509)$

\begin{tabular}{|c|c|c|c|c|}
\hline Gender & \multicolumn{2}{|c|}{ Age } & \multirow{2}{*}{\multicolumn{2}{|c|}{$\begin{array}{c}\text { Orientation Group of } \\
\text { the Last Grade in Lyceum } \\
\text { "Science" }(23 \%)\end{array}$}} \\
\hline "Male" (29\%) & $"<=30 "(17 \%)$ & "41-50" (23\%) & & \\
\hline \multirow[t]{2}{*}{ "Female" (71\%) } & "31-40" (26\%) & ">=51" (34\%) & \multicolumn{2}{|c|}{ "Economic \& Computer" (21\%) } \\
\hline & & & \multicolumn{2}{|c|}{ "Humanities" (56\%) } \\
\hline \multicolumn{2}{|c|}{$\begin{array}{c}\text { Teaching } \\
\text { experience (years) }\end{array}$} & $\begin{array}{l}\text { Postgradute } \\
\text { studies }\end{array}$ & \multicolumn{2}{|c|}{$\begin{array}{l}\text { Teaching } \\
\text { Grade }\end{array}$} \\
\hline "<=5" (17\%) & "11-20" (38\%) & "Yes" (53\%) & "First - Second" (9\%) & "Fifth - Sixth" (25\%) \\
\hline "6-10" (7\%) & ">=21" (38\%) & "No" (47\%) & "Trird - Fourth" (8\%) & "Combination" (58\%) \\
\hline
\end{tabular}

\subsection{Instrument}

We adapted the "The Science Teaching Efficacy Belief Instrument" (STEBI-A) (Riggs, \& Enochs, 1990) to measure in-service elementary teachers' self-efficacy in teaching biological concepts. This instrument was selected because a) it was constructed to measure the self-efficacy of in-service elementary teachers in science and b) it is a highly valid and reliable instrument.

STEBI-A consists of two subscales: a) Personal Science Teaching Efficacy (PSTE) and b) Science Teaching Outcome Expectancy (STOE). The seminal authors of STEBI-A conducted their research on practicing elementary teachers $(\mathrm{N}=331)$ and they reported Cronbach's Alpha values of 0.92 for PSTE and 0.77 for STOE. Finally, it is important to be noted that STEBI-A instrument has been used not only in America (Flores, 2015; Moslemi \& Mousavi, 2019), Australia (Mulholland et al., 2004) and Europe (Koutsianou \& Emvalotis, 2019) but also in countries such as China (Sang et al. 2012), Ecuador (Lucero et al. 2013), India (Desouza et al. 2004), Iran (Fathi-Azar 2002), Israel (Eshach 2003), Taiwan (Liu et al. 2008) and the United Arab Emirates (McKinnon et al. 2014), a fact that proves the reliability and validity of the instrument and the increased interest for science. In our survey, data were collected using a questionnaire. The first section of our instrument included items regarding teachers' general characteristics (e.g. group of age, gender, years of teaching experience, and special studies in Biology, etc). The second section consisted of the 13 statements of Personal Biology Teaching Efficacy Belief Scale (PBTE) of bio-STEBI-A and third section consisted of the 12 items of Biology Teaching Outcome Expectancy Scale (BTOE) of bio-STEBI-A. All items were scored on a Likert scale, ranging from $1=$ strongly disagree to $5=$ strongly agree. We replaced the word "science" with the word "biological contents" in order for the exact meaning to be conveyed. Initially, the pilot questionnaire was delivered to 40 advanced elementary teachers, asking them to complete it and comment on the comprehension of the statements and identify possible fuzziness in their formulation. These teachers were 
excluded from the final sample. The online pilot questionnaire was answered by 36 teachers during the period $1 / 4 / 20$ to $10 / 4 / 20$. Statistical analysis showed that there was a low correlation between some statements of both subscales. Specifically, in the statements of the first sub-scale, concerning the beliefs of personal self-efficacy in teaching biological concepts, the statements PBTE_2 and PBTE_8 showed a low correlation and in the statements of the second sub-scale, which concerned the outcome expectancy, the statements BTOE_10, BTOE_14, BTOE_20 and BTOE_25 showed a low correlation, too. These statements have been formulated again. Also, some statements were modified in terms of their wording after the comments of the participants in the pilot research.

\section{Results}

The data were analysed using SPSS software. Regarding the distribution of teachers' responses in most items both for the Personal Biology Teaching Efficacy beliefs (PBTE) and for the Biology Teaching Outcome Expectancy beliefs (BTOE), the participants mainly took a neutral position. Table 2 shows the responses' distribution of teachers $(\mathrm{N}=509)$ who participated in our survey.

Regarding the first sub-scale (PBTE) as shown in Table 2, and as far as the positively worded statements are concerned, the majority of the participants (sum of agree and strongly agree) (72.3\%) answered that they encourage students to ask questions and a high percentage of participants (57\%) answered that they are constantly trying to find more effective ways to teach biological concepts. Respectively, a significant percentage (53.6\%) agreed that they are typically able to answer their students' questions about biological concepts and $46.7 \%$ of them answered that they understand biological concepts well enough to be effective in teaching them in Primary Education. On the same subscale and with regard to the negatively stated statements, the majority (sum of disagree and absolute disagree) (60.3\%) answered that they disagree that they are confused about how to help their students understand biological concepts when they have difficulty understanding them, and more than half $(51.7 \%)$ of them answered that they disagree that they do not know what to do, to turn their students towards biological concepts. Moreover, a high percentage of the participants (45.6\%) disagreed that they have difficulties in explaining to the students how the experiments related to biological concepts work, while $43.4 \%$ would invite the principal to evaluate their teaching of biological concepts.

In the second subscale (BTOE), the majority $(84.1 \%)$ believed that students' insufficient knowledge of biological concepts can be improved by effective teaching. A significant percentage $(75.6 \%)$ answered that when the level of students' understanding of biological concepts is improved, it is because the teacher finds an effective teaching method. Almost half of them (48.7\%) agreed that students' poor performance in biological concepts is probably due to ineffective teaching and $47.5 \%$ answered that students' performance in biological concepts is related to the teacher's effectiveness in teaching biological concepts. Respectively, in the negatively worded statements, half of the 
participants $(49.8 \%)$ disagreed with the statement that the effectiveness in teaching biological concepts does not affect the performance of students with low motivation to learn and about half of them (49.3\%) disagreed with the statement that teachers cannot help some students to understand biological concepts no matter how well they teach them. Moreover, a significant percentage (38.3\%) disagreed with the statement that increased effort in biological concepts teaching produces little change in some students' biological concepts achievements and 30.1\% disagreed with the statement that the low performance of some students in biological concepts is not the fault of the teachers.

Table 2: Responses' distribution of teachers $(\mathrm{N}=509)$

\begin{tabular}{|c|c|c|c|c|c|}
\hline & SD & D & $\mathbf{U N}$ & A & SA \\
\hline \multicolumn{6}{|l|}{ A. Personal Biology Teaching Efficacy (PBTE) } \\
\hline $\begin{array}{l}\text { 2. I am continually finding more effective ways to teach } \\
\text { biological concepts. }\end{array}$ & $1.8 \%$ & $8.4 \%$ & $32.8 \%$ & $35.6 \%$ & $21.4 \%$ \\
\hline $\begin{array}{l}3^{*} \text {. Even when I try very hard, I don't teach biological } \\
\text { concepts as effectively as I do most subjects }\end{array}$ & $11.8 \%$ & $26.1 \%$ & $37.7 \%$ & $18.9 \%$ & $5.5 \%$ \\
\hline 5. I know how to teach biological concepts effectively & $5.3 \%$ & $23.2 \%$ & $44.6 \%$ & $22.8 \%$ & $4.1 \%$ \\
\hline $\begin{array}{l}6^{*} . I \text { am not very effective in monitoring biological concepts } \\
\text { experiments. }\end{array}$ & $9.4 \%$ & $27.1 \%$ & $45.4 \%$ & $12.8 \%$ & $5.3 \%$ \\
\hline $\begin{array}{l}8^{*} \text {. I generally teach biological concepts } \\
\text { ineffectively. }\end{array}$ & $6.1 \%$ & $31.8 \%$ & $44.2 \%$ & $15.3 \%$ & $2.6 \%$ \\
\hline $\begin{array}{l}\text { 12. I understand biological concepts well enough to be } \\
\text { effective in teaching them in Primary Education. }\end{array}$ & $2.8 \%$ & $13.6 \%$ & $36.9 \%$ & $37.3 \%$ & $9.4 \%$ \\
\hline $\begin{array}{l}17^{*} . \text { I find it difficult to explain to students how biological } \\
\text { concepts experiments work. }\end{array}$ & $11.2 \%$ & $34.4 \%$ & $35.4 \%$ & $15.9 \%$ & $3.1 \%$ \\
\hline $\begin{array}{l}\text { 18. I am typically able to answer students' biological concepts } \\
\text { questions. }\end{array}$ & $1.4 \%$ & $9.0 \%$ & $36.0 \%$ & $43.4 \%$ & $10.2 \%$ \\
\hline $\begin{array}{l}19^{*} \text { I wonder if I have the necessary skills to teach biological } \\
\text { concepts. }\end{array}$ & $1.8 \%$ & $23.0 \%$ & $33.4 \%$ & $24.6 \%$ & $8.3 \%$ \\
\hline $\begin{array}{l}21^{*} \text {. Given a choice, I would not invite the principal to } \\
\text { evaluate my biological concepts teaching. }\end{array}$ & $21.8 \%$ & $21.6 \%$ & $29.1 \%$ & $15.1 \%$ & $12.4 \%$ \\
\hline $\begin{array}{l}22^{*} \text {. When a student has difficulty understanding biological } \\
\text { concepts, I am usually at a loss on how to help the student } \\
\text { understand it better. }\end{array}$ & $22.0 \%$ & $38.3 \%$ & $27.9 \%$ & $10.0 \%$ & $1.8 \%$ \\
\hline $\begin{array}{l}\text { 23. When I teach biological concepts, I usually welcome } \\
\text { student questions. }\end{array}$ & $.6 \%$ & $5.3 \%$ & $21.8 \%$ & $46.2 \%$ & $26.1 \%$ \\
\hline $\begin{array}{l}24^{*} . \text { I don't know what to do to turn students on to biological } \\
\text { concepts. }\end{array}$ & $16.3 \%$ & $35.4 \%$ & $32.6 \%$ & $13.2 \%$ & $2.6 \%$ \\
\hline \multicolumn{6}{|l|}{ B. Biology Teaching Outcome Expectancy (BTOE) } \\
\hline $\begin{array}{l}\text { 1. When a student does better than usual in biological } \\
\text { concepts, it is because the teacher exerted an extra effort. }\end{array}$ & $2.0 \%$ & $12.6 \%$ & $47.5 \%$ & $34.0 \%$ & $3.9 \%$ \\
\hline $\begin{array}{l}\text { 4. When the biological concepts grades of students improve, it } \\
\text { is most often due to their teacher finding a more effective } \\
\text { teaching approach. }\end{array}$ & $.0 \%$ & $1.8 \%$ & $22.6 \%$ & $63.1 \%$ & $12.6 \%$ \\
\hline $\begin{array}{l}\text { 7. If students are underachieving in biological concepts, it is } \\
\text { most likely due to ineffective science teaching. }\end{array}$ & $1.0 \%$ & $12.2 \%$ & $38.1 \%$ & $43.0 \%$ & $5.7 \%$ \\
\hline $\begin{array}{l}\text { 9. The inadequacy of a student's biological concepts } \\
\text { background can be overcome by effective teaching. }\end{array}$ & $.0 \%$ & $1.8 \%$ & $14.1 \%$ & $58.2 \%$ & $25.9 \%$ \\
\hline $\begin{array}{l}10^{*} \text { Teachers are not to blame for the low performance of } \\
\text { some students in biological concepts }\end{array}$ & $2.6 \%$ & $27.5 \%$ & $5.3 \%$ & $16.9 \%$ & $2.8 \%$ \\
\hline
\end{tabular}




\begin{tabular}{|c|c|c|c|c|c|}
\hline $\begin{array}{l}\text { 11. When a low achieving child progresses in biological } \\
\text { concepts, it is usually due to the extra attention given by the } \\
\text { teacher. }\end{array}$ & $1.0 \%$ & $6.5 \%$ & $42.0 \%$ & $44.4 \%$ & $6.1 \%$ \\
\hline $\begin{array}{l}13^{*} \text {. Increased effort in biological concepts teaching produces } \\
\text { little change in some students' science achievement. }\end{array}$ & $6.9 \%$ & $31.4 \%$ & $33.0 \%$ & $27.1 \%$ & $1.6 \%$ \\
\hline $\begin{array}{l}\text { 14. The teacher is generally responsible for the achievement of } \\
\text { students in biological concepts. }\end{array}$ & $2.0 \%$ & $14.3 \%$ & $53.2 \%$ & $26.9 \%$ & $3.5 \%$ \\
\hline $\begin{array}{l}\text { 15. Students' achievement in biological concepts is directly } \\
\text { related to their teacher's effectiveness in biological concepts } \\
\text { teaching. }\end{array}$ & $1.0 \%$ & $8.1 \%$ & $43.4 \%$ & $43.2 \%$ & $4.3 \%$ \\
\hline $\begin{array}{l}\text { 16. If parents comment that their child is showing more } \\
\text { interest in biological concepts at school, it is probably due to } \\
\text { the performance of the child's teacher. }\end{array}$ & $.4 \%$ & $4.3 \%$ & $34.6 \%$ & $51.7 \%$ & $9.0 \%$ \\
\hline $\begin{array}{l}20^{*} \text {. Effectiveness in teaching biological concepts does not } \\
\text { greatly affect the performance of low-motivated students }\end{array}$ & $8.1 \%$ & $41.7 \%$ & $4.5 \%$ & $9.4 \%$ & $.4 \%$ \\
\hline $\begin{array}{l}25^{*} \text {. No matter how well the teacher teaches the biological } \\
\text { concepts, he/she cannot help some children to understand the } \\
\text { biological concepts in depth. }\end{array}$ & $12.4 \%$ & $36.9 \%$ & $32.8 \%$ & $15.1 \%$ & $2.8 \%$ \\
\hline
\end{tabular}

\section{Discussion}

The goal of this study was to present Personal Biology Teaching Efficacy Beliefs and Biology Teaching Outcome Expectancy of Greek in-service elementary teachers. Because the literature review drew a minimal number of surveys related to in-service elementary teachers' self-efficacy in teaching biological concepts in this article, the comparison was made with surveys investigating pre-service elementary teachers' self-efficacy, too. According to our findings, Greek in-service elementary teachers scored moderate selfefficacy. This data led to the conclusion that the Greek in-service elementary teachers have little doubt regarding their ability to teach biological concepts and their ability to affect students' achievements.

Our findings are in accordance with the results of the Mavrikaki and Athanasiou research, in Greek in-service elementary teachers. These researchers measured in-service elementary teachers' self-efficacy in terms of personal self-efficacy beliefs and found that Greek primary school self-efficacy in biology teaching is moderate to high. Additionally, our findings agree with the results of research on pre-service elementary teachers of Ekici, Fettahlıoğlu and Çıbık (2012), who found that self-efficacy beliefs of the students studying in the Department of Biology Teaching and Department of Biology, are at the middle level and also with the results of the research Saribas, Teksoz and Ertepinar (2014), who found that students' self-efficacy beliefs related to environmental education and environmental knowledge are both moderate.

\section{Implications and Limitations}

The present study contributes to the existing literature by providing preliminary data regarding the instrument bio-STEBI-A, which measure in-service elementary teachers' self-efficacy beliefs in teaching biological concepts. 
The results of our research raise questions about the factors that affect teachers' self-efficacy. Bandura (1997) mentions as important factors that shape self-efficacy the mastery experiences, which relate to the experiences of the individual; the vicarious experiences, which are affected by role models; the verbal persuasion, which can take the form of positive feedback from the supervisor or colleagues; and the physiological and affective states, regarding an individual's perception of his own physiological and emotional situations. Hence, to improve the self-efficacy of teachers, the above sources could be utilized through appropriately designed teacher professional development courses.

Given that teachers' self-efficacy beliefs influence (Gibson \& Dembo, 1984; Guskey, 1988) their teaching behaviour and affect the motivation and achievement of students (Tschannen-Moran \& Woolfolk-Hoy, 2001), there is an urgent need to create professional development courses, which will boost knowledge skills and attitudes that improve teachers' self-efficacy in teaching biological concepts. These courses should evaluate the self-efficacy of the participants at the beginning and at the end of the courses to record if there was an improvement. Posnanski (2002) reported that personal self-efficacy beliefs increased after the participation of elementary in-service teachers in teachers' professional development courses regarding biological concepts. In addition, the results of these courses can also help teachers clarify their beliefs, think about their attitudes and practices, and subsequently modify their behaviour.

Concluding, it is important to note that the results of the present study should be interpreted in the light of some limitations. The results cannot be generalized due to the convenience sampling which was adopted and the lack of previous research in in-service elementary teachers in teaching the biological concepts. However, further research needs to be carried out to confirm our findings.

Future research can use quantitative and qualitative methods to investigate teachers' self-efficacy in teaching biological concepts and the effect of personal characteristics of teachers and the school environment on the self-efficacy of teachers in the teaching of biological concepts.

\section{About the Author(s)}

Eirini Tzovla is a Director of Primary school. He has a Bachelor Degree in Education, a master of Education and a master in Adult Education. She is a $\mathrm{PhD}$ candidate at the Department of Molecular Biology and Genetics of the Democritus University of Thrace and her research interests include utilization of digital technologies in the Education, Distance Education and Adult Education. She works as a detached member in the Laboratory of Teaching and Professional Development of Bioscientists.

Katerina Kedraka (BA, MSc, PhD) is an Associate Professor of Teaching and Job Skills of Bioscientists in the Department of Molecular Biology and Genetics in Democritus University of Thrace. Her research and publications in international and Greek conferences, as well as in scientific journals, focus on Adult Education, Career Management, Pedagogy and Didactics. She is the Head of a master's degree "Didactics 
of Biosciences" and she leads the Lab "Teaching and Professional Development of Bioscientists". Recently she has been appointed as the manager of the Teaching and Learning Center of Democritus University of Thrace. Her scientific interests focus on University Pedagogy, Adult Education / Lifelong Learning, Career Management, Guidance, Gender Issues in education and employment. A section in which can be presented in a detailed way authors(s) activities, research interests, memberships and affiliations, published research, etc.

\section{References}

Akgün, A. E., Keskin, H., \& Byrne, J. (2009). Organizational emotional capability, product and process innovation, and firm performance: An empirical analysis. Journal of Engineering and Technology Management, 26(3), 103-130. 10.1016/j.jengtecman.2009.06.008

Albion, P. R., \& Spence, K. G. (2013). Primary Connections in a provincial Queensland school system: Relationships to science teaching self-efficacy and practices. International Journal of Environmental and Science Education, 8(3), 501-520. DOI: 10.12973/ijese.2013.215a

Angle, J., \& Moseley, C. (2009). Science teacher efficacy and outcome expectancy as predictors of students' end-of-instruction (EOI) biology I test scores. School Science and Mathematics, 109(8), 473-483. https://doi.org/10.1111/j.1949-8594.2009.tb18294.x

Ateş, H., \& Saylan, A. (2015). Investigation of Pre-Service Science Teachers' Academic Self-Efficacy and Academic Motivation toward Biology. International Journal of Higher Education, 4(3), 90-103. DOI: https://doi.org/10.3402/rlt.v22.20889

Aurah, Catherine M., and Tom J. McConnell. "Comparative Study on Pre-Service Science Teachers' Self-Efficacy Beliefs of Teaching in Kenya and the United States of America; USA." American Journal of Educational Research 2.4 (2014): 233-239. DOI: 10.12691/education-2-4-9

Aydin, S., \& Boz, Y. (2010). Pre-service elementary science teachers' science teaching efficacy beliefs and their sources. Elementary Education Online, 9(2), 694-704.

Baldwin, J. A., Ebert-May, D., \& Burns, D. J. (1999). The development of a college biology self-efficacy instrument for nonmajors. Science Education, 83(4), 397408.https://doi.org/10.1002/(SICI)1098-237X(199907)83:4<397::AIDSCE1>3.0.CO;2-\%23.

Bandura, A. (1977). Self-efficacy: toward a unifying theory of behavioral change. Psychological review, 84(2), 191. https://doi.org/10.1037/0033-295X.84.2.191

Bandura, A. (1982). Self-efficacy mechanism in human agency. American psychologist, 37(2), 122. https://doi.org/10.1037/0033-295X.84.2.191

Bandura, A. (1997). Self-efficacy and health behaviour. Cambridge handbook of psychology, health and medicine, 160-162. 
Bayraktar, S. (2011). Turkish preservice primary school teachers' science teaching efficacy beliefs and attitudes toward science: The effect of a primary teacher education program. School Science and Mathematics, 111(3), 83-92. https://doi.org/10.1111/j.1949-8594.2010.00065.x

Bergman, D. J., \& Morphew, J. (2015). Effects of a science content course on elementary preservice teachers' self-efficacy of teaching science. Journal of College Science Teaching, 44(3), 73-81.

Bleicher, R. E. (2007). Nurturing confidence in preservice elementary science teachers. Journal of Science Teacher Education, 18(6), 841-860. https://doi.org/10.1007/s10972-007-9067-2.https://doi.org/10.1007/s10972-007$\underline{9067-2}$

Brouwers, A., \& Tomic, W. (2000). A longitudinal study of teacher burnout and perceived self-efficacy in classroom management. Teaching and Teacher Education, 16(2), 239253. https://doi.org/10.1016/S0742-051X(99)00057-8

Brownell, M. T., \& Pajares, F. (1999). Teacher efficacy and perceived success in mainstreaming students with learning and behavior problems. Teacher Education and Special Education, 22(3), 154-164. https://doi.org/10.1177/088840649902200303

Bryce, R., Oliver, M. K., Davies, L., Gray, H., Urquhart, J., \& Lambin, X. (2011). Turning back the tide of American mink invasion at an unprecedented scale through community participation and adaptive management. Biological Conservation, 144(1), 575-583. https://doi.org/10.1016/j.biocon.2010.10.013

Bursal, M. (2012). Perceived peer support and personal science teaching efficacy beliefs of preservice elementary teachers. Journal of Turkish Science Education, 9(4), 10-21.

Çimen, O., Gökmen, A., Altunsoy, S., Ekici, G., \& Y1lmaz, M. (2011). Analysis of biology candidate teachers' self-efficacy beliefs on environmental education. ProcediaSocial and Behavioral Science, 15, 2549-2553. DOI: 10.1016/j.sbspro.2011.04.143

Cox, C. A., \& Carpenter, J. R. (1989). Improving attitudes toward teaching science and reducing science anxiety through increasing confidence in science ability in inservice elementary school teachers. Journal of Elementary Science Education, 1(2), 14-34.

Dellinger, A. B., Bobbett, J. J., Olivier, D. F., \& Ellett, C. D. (2008). Measuring teachers' self-efficacy beliefs: Development and use of the TEBS-Self. Teaching and teacher education, 24(3), 751-766.

Demirci, F., \& Ozyurek, C. (2018). Astronomy Teaching Self-Efficacy Belief Scale: The Validity and Reliability Study. Journal of Education and Learning, 7(1), 258-271. DOI: 10.5539/jel.v7n1p258

Ekici, G., Fettahlığlu, P., \& Çıbık, A. S. (2012). Biology Self Efficacy Beliefs of the Students Studying in the Department of Biology and Department of Biology Teaching. International Online Journal of Educational Science, 4(1).

Emmer, E. T., \& Hickman, J. (1991). Teacher efficacy in classroom management and discipline. Educational and psychological measurement, 51(3), 755-765. https://doi.org/10.1177/0013164491513027 
Enochs, L. G., Riggs, I. M., \& Sc Ellis, J. D. (1993). The Development and Partial Validation of Microcomputer Utilization in Teaching Efficacy Beliefs Instrument in a Science Setting. School Science and Mathematics, 93, 257-263.

Enochs, L. G., Smith, P. L., \& Huinker, D. (2000). Establishing factorial validity of the mathematics teaching efficacy beliefs instrument. School Science and Mathematics, 100(4), 194-202. https://doi.org/10.1111/j.1949-8594.2000.tb17256.x

Evans, R. (2012). Active strategies during inquiry-based science teacher education to improve long-term teacher self-efficacy. In Daugbjerg, P. S. (Eds.), Proceedings of Science teachers' narratives on motivation and commitment: A story about recruitment and retention. Paper presented at European Science Education Research Association, Lyon, France.

Fives, H., \& Buehl, M. M. (2012). Spring cleaning for the "messy" construct of teachers' beliefs: What are they? Which have been examined? What can they tell us? In K. R. Harris, S. Graham, T. Urdan, S. Graham, J. M. Royer, \& M. Zeidner (Eds.), APA handbooks in psychology®. APA educational psychology handbook, Vol. 2. Individual differences and cultural and contextual factors (p. 471-499). American Psychological Association. https://doi.org/10.1037/13274-019

Flores, I. M. (2015). Developing Preservice Teachers' Self-Efficacy through Field-Based Science Teaching Practice with Elementary Students. Research in Higher Education Journal, 27.

Gerçek, C., Yılmaz, M., Köseoğlu, P., \& Soran, H. (2006). Biology teaching self-efficacy beliefs of the teacher candidates. Ankara University. Journal of Faculty of Educational Science, 39(1), 57-73. https://doi.org/10.1016/j.sbspro.2014.05.364

Gibson, S., \& Dembo, M. (1984). Teacher efficacy: A construct validation. Journal of Educational Psychology, 76(4), 569-582. https://doi.org/10.1037/0022-0663.76.4.569

Gosselin, D. C., Thomas, J., Redmond, A., Larson-Miller, C., Yendra, S., Bonnstetter, R. J., \& Slater, T. F. (2010). Laboratory earth: A model of online K-12 teacher coursework. Journal of Geoscience Education, 58(4), 203-213.

Gunning, A. M., \& Mensah, F. M. (2011). Preservice elementary teachers' development of self-efficacy and confidence to teach science: A case study. Journal of Science Teacher Education, 22(2), 171-185. DOI: 10.1007/s10972-010-9198-8

Guskey, T. R. (1988). Teacher efficacy, self-concept, and attitudes toward the implementation of instructional innovation. Teaching and teacher education, 4(1), 6369. https://doi.org/10.1016/0742-051X(88)90025-X

Hechter, R. P. (2011). Changes in preservice elementary teachers' personal science teaching efficacy and science teaching outcome expectancies: The influence of context. Journal of science teacher education, 22(2), 187-202. https://doi.org/10.1007/s10972-010-9199-7

Kennedy, K. J., \& Hui, S. K. (2006). Developing teacher leaders to facilitate Hong Kong's curriculum reforms: Self-efficacy as a measure of teacher growth. International Journal of Educational Reform, 15(1), 114-128. 
Koutsianou, A., \& Emvalotis, A. (2019). Greek Pre-Service Primary Teachers' Efficacy Beliefs in Science and Mathematics Teaching: Initial Adaptation of the STEBI-B and MTEBI Instruments. International Journal of Educational Methodology, 5(3), 375385. DOI 10.12973/ijem.5.3.375.

Lakshmanan, A., Heath, B. P., Perlmutter, A., \& Elder, M. (2010). The impact of science content and professional learning communities on science teaching efficacy and standards-based instruction. Journal of research in science teaching, 48(5), 534-551. https://doi.org/10.1002/tea.20404

Liu, C. J., Jack, B. M., \& Chiu, H. L. (2008). Taiwan elementary teachers' views of science teaching self-efficacy and outcome expectations. International Journal of Science and Mathematics Education, 6(1), 19-35. DOI: 10.1007/s10763-006-9065-4

Lumpe, A., Czerniak, C., Haney, J., \& Beltyukova, S. (2012). Beliefs about teaching science: The relationship between elementary teachers' participation in professional development and student achievement. International Journal of Science Education, 34(2), 153-166. DOI: 10.1080/09500693.2010.551222

Malandrakis, G. (2018). Influencing Greek pre-service teachers' efficacy beliefs and selfconfidence to implement the new 'Studies for the Environment 'curricula. Environmental Education Research, 24(4), 537-563. https://doi.org/10.1080/13504622.2016.1272672

Mavrikaki, E., \& Athanasiou, K. (2011). Development and application of an instrument to measure Greek primary education teachers' biology teaching self-efficacy beliefs. Eurasia Journal of Mathematics, Science and Technology Education, 7(3), 203213. DOI: $10.12973 /$ ejmste/75197

McKinnon, M., Moussa-Inaty, J., \& Barza, L. (2014). Science teaching self-efficacy of culturally foreign teachers: A baseline study in Abu Dhabi. International Journal of Educational Research, 66, 78-89. DOI: 10.1016/j.ijer.2014.03.001

Mojavezi, A., \& Tamiz, M. P. (2012). The Impact of Teacher Self-Efficacy on the Students' Motivation and Achievement. Theory and Practice in Language Studies, 2, 483-491. https://doi.org/10.4304/tpls.2.3.483-491

Norris, C. M., Morris, J. E., \& Lummis, G. W. (2018). Preservice teachers' self-efficacy to teach primary science based on 'science learner' typology. International Journal of Science Education, 40(18), 2292-2308. DOI: https://doi.org/10.1080/09500693.2018.1528645

Moslemi, N., \& Mousavi, A. (2019). A psychometric re-examination of the science teaching efficacy and beliefs instrument (STEBI) in a Canadian context. Education Science, 9(1), 17. https://doi.org/10.3390/educsci9010017

Pajares, F. (1996). Self-efficacy beliefs in academic settings. Review of educational research, 66(4), 543-578. https://doi.org/10.3102/00346543066004543

Posnanski, T. J. (2002). Professional development programs for elementary science teachers: An analysis of teacher self-efficacy beliefs and a professional development model. Journal of Science Teacher Education, 13(3), 189-220. https://doi.org/10.1023/A:1016517100186 
Riggs, I., \& Enochs, L. (1990). Toward the development of an elementary teacher's science teaching efficacy belief instrument. Science Education, 74, 625-638. https://doi.org/10.1002/sce.3730740605

Rotter, J. B. (1966). Generalized expectancies for internal versus external control of reinforcement. Psychological monographs: General and applied, 80(1), 1.

Rubeck, M. L. H. (1990). Path analytical models of variables that influence science and chemistry teaching self-efficacy and outcome expectancy in middle school science teachers (Doctoral dissertation, Kansas State University, Kansas).

Saribas, D., Teksoz, G., \& Ertepinar, H. (2014). The relationship between environmental literacy and self-efficacy beliefs toward environmental education. Procedia-Social and Behavioral Science, 116(2), 3664-3668. DOI: 10.1016/j.sbspro.2014.01.820

Sarikaya, H., Cakiroglu, J., \& Tekkaya, C. (2005). Self-efficacy, attitude and science knowledge. Academic Exchange Quarterly, 9(4), 38-43. https://doi.org/10.1007/s10763-009-9179-6.

Savran, A., \& Çakiroğlu, J. (2001). Preserve biology teachers' perceived efficacy beliefs in teaching biology. Hacettepe Üniversitesi Eğitim Fakültesi Dergisi, 21(21).

Shum, L. C., \& Cheng, Y. C. (1997). Perceptions of women principals' leadership and teachers' work attitudes. Journal of Educational Administration. 10.1108/09578239710161786

Smolleck, L. D., Zembal-Saul, C., \& Yoder, E. P. (2006). The development and validation of an instrument to measure preservice teachers' self-efficacy in regard to the teaching of science as inquiry. Journal of Science Teacher Education, 17(2), 137-163. https://doi.org/10.1007/s10972-006-9015-6

Snyder, J. A. (2020). "Higher Education in the Age of Coronavirus". Boston Review http://bostonreview.net/forum/jeffrey-aaron-snyder-higher-education-agecoronavirus

Thomas, J., Ivey, T., \& Puckette, J. (2013). Where is Earth Science? Mining for opportunities in chemistry, physics, and biology. Journal of Geoscience Education, 61(1), 113-119. DOI: 10.5408/12-319.1

Tschannen-Moran, M., Hoy, A. W., \& Hoy, W. K. (1998). Teacher efficacy: Its meaning and measure. Review of educational research, 68(2), 202-248.

Tschannen-Moran, M., \& Woolfolk Hoy, A. (2001). Teacher Efficacy: Capturing an Elusive Construct. Teaching and Teacher Education, 17, 783-805. http://dx.doi.org/10.1016/S0742-051X(01)00036-1

UNESCO Institute for Statistics Data. (2020). COVID-19 Impact on Education. UNESCO. Available: https://en.unesco.org/covid19/educationresponse

Usher, E. L., \& Pajares, F. (2008). Sources of self-efficacy in school: Critical review of the literature and future directions. Review of educational research, 78(4), 751-796. https://doi.org/10.3102/0034654308321456

Yenice, N. (2009). Search of science teachers' teacher efficacy and self-efficacy levels relating to science teaching for some variables. Procedia social and behavioral science, 1(1), 1062-1067. DOI: 10.1016/j.sbspro.2009.01.191 
Yeung, K. W., \& Watkins, D. (2000). Hong Kong student teachers' personal construction of teaching efficacy. Educational Psychology, 20(2), 213-235. https://doi.org/10.1080/713663713

Yılmaz, M., Güneş, P., \& Katircioğlu, H. T. (2016). Examination of the teacher self-efficacy of pre-service biology and science teachers in terms of different variables. Journal of Turkish Science Education, 13(1), 45-54. 

to copy, distribute, transmit or adapt the article content, providing a proper, prominent and unambiguous attribution to the authors in a manner that makes clear that the materials are being reused under permission of a Creative Commons License. Views, opinions and conclusions expressed in this research article are views, opinions and conclusions of the author(s). Open Access Publishing Group and European Journal of Education Studies shall not be responsible or answerable for any loss, damage or liability caused in relation to/arising out of conflicts of interest, copyright violations and inappropriate or inaccurate use of any kind content related or integrated into the research work. All the published works are meeting the Open Access Publishing requirements and can be freely accessed, shared, modified, distributed and used in educational, commercial and non-commercial purposes under a Creative Commons Attribution 4.0 International License (CC BY 4.0). 